\title{
Indoor Air Quality and Symptoms of Acute Respiratory Infection in Children Under Five in Marunda Public Flats North Jakarta
}

\author{
Sonia Nur Anggraeni, Dewi Utami Iriani \\ Public Health Study Program, Faculty of Medicine and Health Sciences \\ Syarif Hidayatullah State Islamic University Jakarta, Indonesia \\ soonianggraeni@gmail.com
}

\begin{abstract}
Acute Respiratory Infection (ARI) is an environment-based disease caused by poor air quality. According to WHO, 1.9 million children die from ARI each year. Indonesia is the fifth country with the highest ARI occurrence in the world. One of the factors that influence the symptom of ARI in infants is indoor air quality. Indoor air quality is influenced by several factors such as, environmental factors inside and outside the home and the behavior of residents. This study aims to determine the description of environmental factors in the home with the symptom of ARI in infants at Marunda Flats, North Jakarta. Environmental factors that will be studied are temperature and humidity in the children's room and occupancy density. This research is descriptive study with quantitative approach. The design is cross sectional with 185 infants as samples. This research is conducted from April to July 2017 and located in Marunda Public Flats, North Jakarta. The results of this study indicate that the proportion of ARI symptom complaints in infants at $28,1 \%$. The percentage of unsuitable air temperature and humidity are $44,9 \%$ and $84,3 \%$ respectively. The percentage of uncertain occupancy density is $85,9 \%$. Most of the respondent have the good habit of opening a window with percentage $66,4 \%$. Respondents who have family members as smokers are $67,6 \%$. Factors that are significantly related to ARI symptoms in infants in this study is indoor air humidity (Pvalue $<\mathbf{0 . 0 5}$ ). It is suggested for public flats resident to maintain the plants on their balcony and flats should not be occupied by more than three people. The results of this study can be used as a basis for further research in public flats.
\end{abstract}

Keywords-Acute Respiratory Infection; Public Flats; Infant; Indonesia

\section{INTRODUCTION}

Acute Respiratory Infection (ARI) is an environment-based disease caused by poor air quality. ARI is a major cause of patient visits at public health center (40\%-60\%) and hospitals (15\%-30\%) in Indonesia [1]. According to data RISKESDAS, it is known that prevalence period of ARI cases in 2007 amounted to $25.5 \%$. and decreased to $25 \%$ by 2013 [2]. The proportion of infant mortality rate due to ARI was the second largest after diarrhea [1]. Meanwhile, the prevalence period of ARI cases in DKI Jakarta in 2013 is higher than the national prevalence period of $25.2 \%$.

Air is a media for ARI to spread. Indoor air quality is one of the factor that can affect public health. About 1,6 million people die from diseases caused by indoor air pollution. Community groups at risk of ARI due to indoor air quality are women and children. This is because most of the time women and children are spent indoors [3].

As the capital city, the occupancy density of Jakarta is so high. It has made the government to build flats as an alternative solution. The densest flats in Jakarta are the Marunda Flats, North Jakarta. To fulfill the resident's needs of health, there is Marunda Public Health Clinic under the work area of the Cilincing Public Health Center.

Based on preliminary study and interview, it is known that the prevalence of ARI occurrence in infants at Cilincing Public Health Clinic in 2015 reaches 60 cases per 1000 and this number increases in 2016 amounted to 67 cases per 1000 . Meanwhile, incidence of ARI occurrence in infants per month from January to March 2017 reached 28,8\%. Based on interviews with Head of Marunda Public Health Clinic and Integrated Management of Infants Health program holder, it is known that ARI is the number one disease in infants in Marunda Flats.

\section{METHODS}

This research is descriptive study with quantitative approach. The design study of this research is cross sectional with 185 infants as samples. This research was conducted from April to July 2017 and located in Marunda Public Flats, North Jakarta. The data was collected with questionnaire and physical indoor air quality measurement. Indoor air quality measurement including indoor air temperature and humidity. It was measured with thermohygrometer.

\section{RESULT}

The study was conducted in 185 Marunda residents that have a toddler with an age range from 0-59 months. Here are the univariate results of this study. 
TABLE I. UNIVARIATE ANALYSIS RESULT

\begin{tabular}{|l|c|c|}
\hline Variable & $\mathbf{n}$ & \% \\
\hline ARI Symptoms & & \\
\hline ARI & 52 & 28.1 \\
\hline Non ARI & 133 & 71.9 \\
\hline $\begin{array}{l}\text { Occupancy Density } \\
\text { Dense } \\
\text { Not dense }\end{array}$ & 159 & 85.9 \\
\cline { 2 - 3 } Indoor Air Humidity & 26 & 14.1 \\
\hline Ineligible & 156 & 84.3 \\
\hline Eligible & 29 & 15.7 \\
\hline Indoor Air Temperature & & \\
\hline Ineligible & 83 & 44.9 \\
\hline Eligible & 102 & 55.1 \\
\hline Opening Window Habit & & \\
\hline Not Good & 64 & 34.6 \\
\hline Good & 121 & 65.4 \\
\hline Smoker In Family & & \\
\hline Smoker & 125 & 67.6 \\
\hline Non Smoker & 60 & 32.4 \\
\hline
\end{tabular}

Table I. shows univariate analysis result in this research. It is know that percentage of ARI symptoms in infants lower than non ARI. Most of respondent live in a dense flats and with low quality of indoor air humidity. Respondent that live in Marunda public flats already have a good habit to open their window regularly. But it is known that most of them still have a smoker in family.

TABLE II. BIVARIATE ANALYSIS RESUlT

\begin{tabular}{|c|c|c|c|c|c|}
\hline \multirow{3}{*}{ Variable } & \multicolumn{4}{|c|}{ ARI Symptoms } & \multirow{3}{*}{$P$ value } \\
\hline & \multicolumn{2}{|c|}{ ARI } & \multicolumn{2}{|c|}{ Non ARI } & \\
\hline & $\mathbf{n}$ & $\%$ & $\mathbf{n}$ & $\%$ & \\
\hline Occupancy Density & & & & & \\
\hline Dense & 45 & 28.3 & 114 & 71.7 & 1.000 \\
\hline Not dense & 7 & 26.9 & 19 & 73.1 & \\
\hline Indoor Air Humidity & & & & & \\
\hline Ineligible & 37 & 23.7 & 119 & 76.3 & 0.004 \\
\hline Eligible & 15 & 51.7 & 14 & 48.3 & \\
\hline Indoor Air Temperature & & & & & \\
\hline Ineligible & 26 & 31.3 & 57 & 68.7 & 0.475 \\
\hline Eligible & 26 & 25.5 & 76 & 74.5 & \\
\hline Opening Window Habit & & & & & \\
\hline Not Good & 18 & 28.1 & 46 & 71.9 & 1.000 \\
\hline Good & 34 & 28.1 & 87 & 71.9 & \\
\hline Smokers in Family & & & & & \\
\hline Smoker & 35 & 28 & 90 & 72 & 1.000 \\
\hline Non Smoker & 17 & 28.3 & 43 & 71.7 & \\
\hline
\end{tabular}

Bivariate analysis results can be seen in Table II. Based on the results of bivariate analysis, it is known that there is one variable that have significant relationship with symptom of ARI. It is indoor air humidity with $\mathrm{P}$ value equal to 0.004 . Variables that do not have a significant relationship at $\alpha=5 \%$ with symptom ARI symptoms in infants is the density of occupancy, indoor air temperature, opening window habit and smoker in family.

\section{DISCUSSION}

\section{A. Occupancy Density}

Status of occupancy density in Marunda Flats obtained from the calculation by dividing the area of the house and the number of residents who live in it. House width in Marunda Flats in each unit is the same, which is $30 \mathrm{~m} 2$. The value of occupancy density is then categorized into a qualified occupancy density and does not meet the requirements in accordance with Ministry of Health Regulation No.1077 in 2011 on Guidelines for Indoor Air Quality. Eligible occupancy density is $>10 \mathrm{~m} 2 /$ person whereas unqualified is $<10 \mathrm{~m} 2 /$ person.

Occupancy density variables did not correlate significantly with ARI symptoms in infants. Researchers assume that there is no relationship between the density of occupancy with ARI symptoms in infants because most of the respondent that live in dense flats do not have infants with ARI symptoms.

The ideal number of occupants in the Marunda Flats is one to three people. In some homes found the number of occupants that live in one flat exceeding three people. The largest number of residents found at the time of the study reached 11 people in one flat.

Residential density can worsen indoor air circulation and facilitate the transmission of diseases, especially infectious airborne disease [4]. The density of flats is also influenced by the layout of flats that coincide between one housewith another house. House density per unit and coinciding layout will increase the potential for disease transmission, especially airborne disease [5].

\section{B. Indoor Humidity \& Temperature}

Humidity and temperature affect the airborne disease spread because it can accelerate the growth of viruses, bacteria or fungi causing respiratory tract infections [6]. There are several factors that can affect humidity and indoor air temperature, such as outside humidity, geographical conditions and ventilation conditions [7]. Humidity conditions and outdoor temperatures around the Marunda Flats tend to be dry and hot with an average outdoor temperature of $33^{\circ} \mathrm{C}$ and $35 \%$ outside humidity. This can be influenced by the location of Flats Marunda which is directly adjacent to the Bay of Jakarta.

Weather conditions in different coastal areas with weather in other areas, because the distance is closer to the sea. Sunlight tends to be brighter in the area around the coast due to the reflection of sunlight from sea level. This causes the air in the coastal areas to be warmer and tend to get hotter by noon [8]. Environment Physical conditions outside the home can affect conditions inside the home. It is evident from the univariate analysis results that most of the indoor air humidity is not eligible and tends to dry.

Dry air humidity can inhibit the growth and development of viruses, bacteria and fungi causing ARI [9]. However, indoor air humidity can lead to other potential health problems because it can lead to layers of paint and wood in furniture fragile. This can increase the content of dust and particulates in the air in 
space [10]. Dry humidity can also make the mucous layer in the eye, nasal cavity, mouth and dry throat [11]. Therefore, the air humidity in the fixed space must be kept within the ideal range.

The results of the cross-table analysis showed that most of ARI symptoms were found in infants living in occupancy with insufficient indoor temperatures. However, the result of bivariate analysis shows that there is no significant relationship at $\alpha=5 \%$ between indoor air temperature with symptom of ARI in infants. The results of this study are in line with research conducted by Pramudiyani (2011) [7] in toddlers in Bergas District, Semarang. The absence of correlation between temperature with symptom of ARI is possible because most of the house withunfit temperature condition have no toddler with symptom of ARI.

\section{Opening Window Habit}

Good air circulation can occur when a householder has a habit of opening windows or ventilation. The habit of opening a window affects the quality of air in the house. By opening the window, the air circulation in the room remains stable [12]. In this study, the habit variable of opening the window did not significantly influence the symptom of ARI. This is because most flats owner already have a habit of opening windows.

Most of residents in Marunda Flats have a habit of opening the window because the air will feel hot when the window is not opened. However, there are some residents who do not open their windows on the grounds of disease-carrying vectors such as mosquitoes and mice going through the window.

There are other factors related to the habit of opening windows that may affect ARI symptoms, such as the long opening window and the cleanliness of the window itself. Marianta's research (2015) [12] shows that the cleanliness of air vents can affect the incidence of ARI in infants. Window or ventilation is a medium of air circulation in the house. Dust that accumulates in the windows can get carried in while air circulation occurs and can contaminate indoor air [13].

The duration of opening a window can also affect the emergence of symptoms of ARI symptoms. The longer the window is open then the potential for ambient air to enter the house is higher. If residential windows are located in areas with low ambient air quality then harmful pollutants contained in air may enter and contaminate indoor air [14]. Moreover, the location of Marunda Flats located within the industrial area, making the ambient air around it has a low quality. PM 2.5 levels in the ambient air area Marunda Flats in 2016 has exceeded the value of quality standards. The PM2.5 pollutant is included into the nanoparticles because of its size of less than 100 nanometers. Its very small size and light weight make the nanoparticles suspended in the air [15]. Nanoparticles can enter the body through ingestion and inhalation pathways and cause negative effects on health. Therefore, in addition to the habit of opening windows, window cleanliness and ventilation must be considered by the residents of the apartment.

\section{Smoker in Family}

This research is not in line with research Indahsari (2016) [17]which states the relationship between exposure to cigarette smoke with symptoms of respiratory symptoms. In the study of
Indahsari (2016) [16] exposure to cigarette smoke is not only examined from the smoking status of family members but the amount of cigarette consumption was investigated.

In this study, it is known that of the respondents who have family members of smokers, $57,6 \%$ of whom smoke outside the home. Each flat in Marunda Flats has a balcony and terrace of the house commonly used for smoking. Smoking habits outside the home used by residents of flats, especially fathers, to socialize with other apartment residents.

The number of respondents who smoke outside the home can affect the results of the study so that the results do not show any significant relationship and tend to be a protective factor. In addition, this study only looked at the relationship of smoking status of family members without looking at the relationship between family members smoking site with symptomatic ARI symptoms in infants.

Suggestion that can be advised for residents of flats are to maintain the plants on the terrace or balcony of the house to regulate the temperature and humidity in the house. Flats should only be inhabited by three to four people per unit. For the next researcher should do further research to see the relationship of several variables that have tendency to be the protective factor in this research, that is; moisture and smoking status of family members. The next researcher should conduct further research on the physical environmental factors outside the home and indoor air pollutant levels.

\section{REFERENCES}

[1] Ministry of Health Indonesia. "Acute Respiratory Infection", 2012.

[2] Ministry of Health Indonesia, "Basic Health Research 2013", Riset Kesehatan Dasar 2013.

[3] R.Perez-Padilla., A.Schilmann and H. Riojas-Rodriguez, "Respiratory health effects of indoor air pollution", International Journal of Tuberculosis and Lung Disease, in press.

[4] U. Fachmi Achmad. "Regional Disease Management (Manajemen Penyakit Berbasis Wilayah)", National Public Health Journal (Jurnal Kesehatan Masyarakat Nasional), in press.

[5] M. Smielowska, M. Marc. "Indoor Air Quality in Public Utility Environments. Environmental Science Pollution Research", in press.

[6] I. Suryani. "Physical Environmental Relation and Population Action With ARI Event In Toddlers in the Work Area of Lubuk Buaya Community Health Center (Hubungan Lingkungan Fisik dan Tindakan Penduduk Dengan Kejadian ARI Pada Balita di Wilayah Kerja Puskesmas Lubuk Buaya)", Andalas Health Journal (Jurnal Kesehatan Andalas), in press.

[7] N. Aris Pramudiyani and G. Nita Prameswari, "Relationship Between Home Sanitation and Behavior with the Incidence of Toddler Pneumonia (Hubungan Antara Sanitasi Rumah dan Perilaku dengan Kejadian Pneumonia Balita)", Public Health Journal (Jurnal Kesehatan Masyarakat), in press.

[8] B. Witherington, D. Witherington, Living Beaches of Georgia and the Carolinas: A Beachcomber's Guide, United States: Pineapple Press, Inc., 2011 .

[9] K. R. Smith, J.M. Samet., I. Romieu, and N. Bruce, “Acute Lower Respiratory Infections in Children Indoor Air Pollution in Developing Countries and Topic Collections Indoor Air Pollution in Developing Countries and Acute Lower Respiratory Infections in Children”, Journal Thorax, in press.

[10] H. Frumkin, Safe and Healthy School Environment, New York: Oxford University Press, 2006.

[11] G. Melvyn Howe, .Environmental Medicine (2nd ed.), Philadephia: Elsevier, 2013.

[12] D. Marianta, "Relationship of House Physical Quality to ARI Event PostDisaster Eruption of Sinabung Mountain in Working Area of Tiganderket 
Karo Sumatera Utara District Health Center in 2015. (Hubungan Kualitas Fisik Rumah Terhadap Kejadian ARI Pasca Bencana Erupsi Gunung Sinabung di Wilayah Kerja Puskesmas Kecamatan Tiganderket Karo Sumatera Utara pada Tahun 2015)", unpublished.

[13] A. Anwar and I. Dharmayanti, "Pneumonia among Children Under Five Years of Age in Indonesia (Pneumonia pada Anak Balita di Indonesia)", Public Health Journal Vol. 8 (Jurnal Kesehatan Masyarakat Vol. 8), in press.

[14] R. Fahimah, E. Kusumowardani, and D. Susanna, "Home Air Quality with Pneumonia Occurrence Under Five Years (Kualitas Udara Rumah dengan Kejadian Pneumonia Anak Bawah Lima Tahun)", Makara Journal Health Research, Vol. 18 (Jurnal Penelitian Kesehatan Makara Vol. 18 ), in press.

[15] US EPA. "Technical Fact sheet - Nanomaterials At a Glance”, US EPA Press, 2014

[16] N. Indahsari, Exposure to Air Pollution in the Home with ARI Incidence in Toddlers in the Working Areas of Malimongan Baru Public Health Center (Hubungan Paparan Polusi Udara dalam Rumah dengan Kejadian
ARI pada Balita di Wilayah Kerja Puskesmas Malimongan Baru)”, unpublished. 